\title{
Interaction between maturity stages and temperature on quality of 'Guarani' blackberries stored under controlled atmosphere
}

\author{
Auri Brackmann ${ }^{1}$ Fabio Rodrigo Thewes ${ }^{1}$ Rogerio de Oliveira Anese ${ }^{2}$ \\ Adriano Roque de Gasperin ${ }^{3}$ Diniz Fronza ${ }^{4}$
}

'Departamento de Fitotecnia, Universidade Federal de Santa Maria (UFSM), Santa Maria, RS, Brasil. E-mail: fthewes@yahoo.com.br. *Corresponding author.

${ }^{2}$ Instituto Federal Santa Catarina (IFSC), Urupema, SC, Brasil.

${ }^{3}$ Emater, Candelária, RS, Brasil.

${ }^{4}$ Colégio politécnico, Universidade Federal de Santa Maria (UFSM), Santa Maria, RS, Brasil.

ABSTRACT: The aim of this research was to evaluate the interaction between maturity stages and temperature on fruit quality of 'Guarani' blackberries stored under controlled atmosphere (CA). The experiment was conducted in a factorial scheme (2x2), evaluating two ripening stages (E1: red-color and E2: black-color of fruits) and two temperatures $\left(1^{\circ} \mathrm{C}\right.$ and $\left.5^{\circ} \mathrm{C}\right)$. The fruit were stored in $\mathrm{CA}\left(10.0 \mathrm{kPa} \mathrm{O}_{2}+15.0 \mathrm{kPa} \mathrm{CO}\right)$ and $98 \pm 1 \%$ of relative humidity (RH). Results showed that the principal component 1 (PC I) and principal component 2 (PC II) corresponded to $92.84 \%$ of the overall variation of the evaluated variables. Harvest should not be performed in the early maturity stage, because 'Guarani' blackberries do not develop all quality of consumer. 'Guarani' blackberries must be stored at $1^{\circ} \mathrm{C}$. The maturity stage showed the major importance in the overall variability of quality parameters when compared to storage temperature.

Key words: Rubus fruticosus, postharvest, fruit quality, small fruit.

Interação entre estádios de maturação e temperatura na qualidade de amora-preta 'Guarani' armazenada em atmosfera controlada

RESUMO: $O$ objetivo deste trabalho foi avaliar a interação entre estádios de maturação e temperatura de armazenamento na qualidade de frutos de amora-preta 'Guarani' armazenados em atmosfera controlada (AC). O experimento foi conduzido em esquema fatorial (2x2), avaliando-se dois estádios de maturação (E1: cor vermelha e E2: cor preta dos frutos) e duas temperaturas $\left(1^{\circ} \mathrm{C}\right.$ e $\left.5^{\circ} \mathrm{C}\right)$. Os frutos foram armazenados em $\mathrm{AC}\left(10.0 \mathrm{kPa} \mathrm{O}_{2}+15.0 \mathrm{~Pa} \mathrm{CO}\right.$ ) e $98 \pm 1 \%$ de umidade relativa. Os resultados mostraram que o componente principal 1 (PC I) e o componente principal 2 (PC II) responderam por 92,84\% de variação das variáveis analisadas. Conclui-se que a colheita não deve ser realizada em estádio de maturação antecipado, pois a amora-preta 'Guarani' não desenvolve todas as características de qualidade para o consumidor. A amora-preta 'Guarani' deve ser armazenada na temperatura de $1^{\circ} \mathrm{C}$. Os estádios de maturação apresentam maior importância na variação dos parâmetros de qualidade quando comparados a temperaturas de armazenamento.

Palavras-chave: Rubus fruticosus, pós-colheita, qualidade de frutos, pequenas frutas.

\section{INTRODUCTION}

During the last years, the small fruits take place commercially, especially because the of its nutraceutical propriety. In order to obtain high quality, blackberries need to be harvest at the correct maturity stage, in the black color of the skin, showing a very fragile structure resulting in short postharvest life (CIA et al., 2007; GONÇALVES et al., 2012; ANTUNES et al., 2014). Thus, is important the development of a technique allowing the harvest at early maturity stage, when fruit show more resistance to mechanical damage, leading in lower quality loss during storage and commercialization. However, 'Guarani' blackberries are non-climacteric fruits and do not respond to ethylene application after harvest, needing the development of other technologies to allow the harvest in early maturity stages.

One possible technology is the increase of storage temperature, what resulted in high metabolism and a advance in maturation during storage. Nowadays there are no researches evaluating different maturity stage on the post storage quality of blackberries and its interaction with the storage temperature. Harvest in early maturity stage is hindered by the low organoleptic quality after storage, but there are studies evaluating the storage temperature above the used commercially in order to allow organoleptic and visual quality acquisition after storage. 
The low temperature is the main factor in metabolism control during postharvest life of fruits. According to CIA et al. (2007) the storage of blackberries under $25^{\circ} \mathrm{C}$ is limited to one day, but when fruits where stored under $5^{\circ} \mathrm{C}$ the storage was extended up to nine days, demonstrating the importance of temperature in quality keeping. Nevertheless, the increase of storage temperature may be an important factor for fruit harvested in early maturity stages, allowing fruit getting the typical texture and flavor after storage under temperatures a little bit above the recommended. Researches evaluating different storage temperature reported its reduction close to $0^{\circ} \mathrm{C}$ kept quality after storage, by lower $\mathrm{pH}$ and higher ascorbic acid (ANTUNES et al., 2003; GONÇALVES et al., 2012). GONÇALVES et al. (2012) reported a reduction higher than $75 \%$ in respiration rate by fruit stored under $0^{\circ} \mathrm{C}$ in relation to fruit stored under $20^{\circ} \mathrm{C}$. The storage temperature is a factor that varies according to some characteristics, such as the maturity stage, but there are no studies evaluating the interaction of storage temperature and maturity stages.

Additionally to low temperature, the control of relative humidity $(\mathrm{RH})$ is a key factor to quality maintenance during postharvest. High $\mathrm{RH}$ resulted in fungal development and decay incidence, but too low RH resulted in excessive mass loss and shriveling (KADER, 1986; SCHWARZ, 1994). Therefore the $\mathrm{RH}$ need to be accurately regulate throughout the storage. Another key factor on storage is the gaseous concentration inside the chamber. The oxygen lowering and carbon dioxide increase further reduced the metabolism of fruit, extending the storage and shelf life (PERKINS VEAZIE \& COLLINS, 2002; BRACKMANN et al., 2012). KADER (2002) recommended, for blackberries storage, an $\mathrm{O}_{2}$ from 5 up to $10 \mathrm{kPa}$ and $\mathrm{CO}_{2}$ from 15 up to $20 \mathrm{kPa}$ partial pressure, considering that high $\mathrm{CO}_{2}$ partial pressure $(>20 \mathrm{kPa})$ reduced the ascorbic acid content (AGAR et al., 1997).

In this context, the aim of the present research was to evaluate the interaction between maturity stages and different temperatures on fruit quality during storage and shelf life of 'Guarani' blackberries under controlled atmosphere storage.

\section{MATERIAL AND METHODS}

The experiment was carried out with 'Guarani' blackberries, picked in two ripening stages, defined according to TOSUN et al. (2008), (E1: red-color and E2: black-color) in an Experimental
Orchard from the Polytechnic School at Universidade Federal de Santa Maria (UFSM), RS, Brazil. After harvest, fruit with any type of damage were eliminated and the experimental samples were homogenized. The experiment was conducted in a completely randomized design, with six replicates of $200 \mathrm{~g}( \pm 10 \mathrm{~g})$. Fruit of the two maturity stages (E1 and E2) were stored in two temperatures (at $1^{\circ} \mathrm{C}$ and at $\left.5^{\circ} \mathrm{C}\right)$, both under $\mathrm{CA}$-condition $\left(10.0 \mathrm{kPa} \mathrm{O}_{2}+15.0 \mathrm{kPa}\right.$ $\mathrm{CO}_{2}$ ) and $98 \pm 1 \%$ of $\mathrm{RH}$ in a factorial arrangement (2 maturity stage $\mathrm{x} 2$ temperatures).

The fruit were stored in a hermetically sealed chamber with $5.0 \mathrm{~L}$, which were placed inside cold storage rooms, at $1^{\circ} \mathrm{C}$ and at $5^{\circ} \mathrm{C}\left( \pm 0.1^{\circ} \mathrm{C}\right)$. Temperature was monitored by thermostats and checked daily with bulb mercury thermometers $\left(\right.$ Inconterm $^{\circledR}$ ) with a $0.1^{\circ} \mathrm{C}$ resolution inserted in the blackberries fruit flesh. The CA installation was carried out immediately after fruit cooling by $\mathrm{O}_{2}$ reduction in the storage chamber with injection of $\mathrm{N}_{2}$ obtained from a pressure swing adsorption (PSA). The elevation of $\mathrm{CO}_{2}$ partial pressures were obtained by gas injection from a high pressure cylinder. The CA conditions were monitored and controlled by automatic gas control equipment (Kronenberger/Climasul, RS, Brazil). The $\mathrm{O}_{2}$ consumed by respiration of fruit was replaced by injections of atmospheric air into the chambers, and excessive $\mathrm{CO}_{2}$ produced by respiration was absorbed passing the air of the chamber through a $40 \%$ potassium hydroxide solution.

Fruit quality and ripening parameters were evaluated after 12 days of storage, plus two days of shelf life at $20^{\circ} \mathrm{C}$. The parameters evaluated were: a) mass loss: obtained through the difference between the total mass before and after the storage, data expressed in percentage of total mass; $b$ ) healthy fruit: determined by the total fruit minus the fruit that showed any symptom of decay incidence, damage, wilting and juice leakage, results expressed in percentage of total fruits; c) soluble solids: obtained by refractometry of the same juice of titratable acidity, results expressed in Brix; d) titratable acidity: determined by titration of a solution that contained $10 \mathrm{~mL}$ of juice diluted in $100 \mathrm{~mL}$ of distillated water, with a solution of $\mathrm{NaOH} 0.1 \mathrm{~N}$, until pH 8.1. Results expressed meq of $\mathrm{NaOH} 100 \mathrm{~mL}$; e) ascorbic acid: determined according to methodology proposed by BRACKMANN et al. (2012), results were expressed in $\mathrm{mg}$ of ascorbic acid by $100 \mathrm{~g}$ of fruit pulp; f) phenolic compounds: were assessed using the FolinCiocalteau phenol reagent method (SINGLETON \& ROSSI, 1965). $5 \mathrm{~mL}$ of bidestilated water and $500 \mu \mathrm{l}$ of Folin-Ciocalteau reagent were added to $200 \mu$ of the 
samples. After $30 \mathrm{~s}$ to $8 \mathrm{~min}, 1.5 \mathrm{ml}$ of sodium carbonate was added. The extract was left to rest for $30 \mathrm{~min}$ at $40^{\circ} \mathrm{C}$. A calibration curve in several dilutions was made based on the absorbance measured at $765 \mathrm{~nm}$ (with a spectrophotometer FEMTO, model 600S). The total phenolic content was expressed as Gallic acid equivalents (GAE) in milligrams per liter; g) respiration rate: determined by $\mathrm{CO}_{2}$ production. Fruits were placed into containers, with $0.8 \mathrm{~L}$ of volume, hermetically sealed for approximately one hour. Air of the container was circulated through an electronic $\mathrm{CO}_{2}$ analyzer, with the infrared gas analyzer (IRGA) system (Agri-datalog, Lana, BZ, Italy). Based on $\mathrm{CO}_{2}$ partial pressure, free room inside the container, fruit mass and closed time, the respiration rate was calculated and expressed in $\mathrm{mL} \mathrm{CO} \mathrm{Kg}^{-1} \mathrm{~h}^{-1} ; \mathrm{h}$ ) juice color: determined with a Minolta colorimeter, model CR 310, with tridimensional color system (CIE L a b). Results were expressed by vertical axis L, which represents color lightness $(0=$ black and $100=$ white $)$, by the $a$ *value, scale that indicated as maximum a red color $(+a)$ and as the minimum a green color $(-a)$, the $b^{*}$ value axis which is ranged from yellow $(+\mathrm{b})$ to blue (- b), intensity of color (Chroma) and hue angle. Analysis of variance (ANOVA) was performed for all the parameters evaluated and compared with the Tukey test at a $5 \%$ probability of error $(\mathrm{P}<0.05)$. The data expressed in percentage were transformed by the formula arc.sen $\sqrt{(x+0,5) / 100}$, before the analysis of variance. An additional multivariate exploratory analysis, called Principal Component Analysis (PCA), was carried out. Before the PCA the data matrix was auto scaled for each variable in order to obtain the same weight for all variables (mean $=0$ and variance $=1$ ). This analysis was carried out with aid of GENES statistical program.

\section{RESULTS AND DISCUSSION}

An exploratory multivariate analysis, called principal component analysis (PCA), was carried out aiming to better visualize the effect of treatments and variables evaluated (Figures $1 \mathrm{~A}$ and $1 \mathrm{~B}$ ). Together, the principal component 1 (PC I) and principal component 2 (PC II) corresponded to $92.84 \%$ of the overall variation. A good separation among treatments was performed by the PCA (Figure 1A). The PC I distinguee the two maturity stage employed on the present study. This result showed that, in blackberries, the maturity stages interferes more on quality than the storage temperature, once the maturity stage are responsible for $59.43 \%$ of the overall variation. Although the PC II has a smaller importance one the overall variation, it was important for separate the two storage temperatures (Figure 1 A). A noteworthy fact is that at the present study the PCA represented almost all the variance of the variables evaluated. In apples, the overall variance was much lower $(54.35 \%)$, where different oxygen levels were evaluated (BOTH et al., 2014).

Concerning the variables, a good separation among all variables was observed by PCA (Figure 1B). Fruits harvested in early maturity stages showed higher healthy fruits and titratable acidity. TOSUN et al. (2008), evaluating nine wild blackberries genotypes, also reported higher titratable acidity in fruits harvested in red color stage (E1). Conversely, fruits harvested in the correct maturity stage (E2), showed higher soluble solids, respiration rate, ascorbic acid and mass loss (Figure 1B).

There was not a significant interaction between the maturity stages and the temperature for mass loss during 'Guarani' blackberries storage (Table 1). Fruit harvested in red-color (E1) early maturity stage presenting a lower mass loss (Table 1). The mass loss occurred in two ways: transpiration and carbon losses by respiration (BRACKMANN et al., 2014). This result is confirmed by the similar response to the treatments of respiration rate and mass loss (Figure 1B), showing high importance of respiration rate on mass loss. Comparing the main effect of the two storage temperatures, there was not observed significant difference for mass loss. Another research evaluating different storage temperatures reported a significant reduction in mass loss by temperature lowering (ANTUNES et al., 2003).

Healthy fruit, which is the amount of fruit for commercialization, was verified a significant interaction between the factors (Table 1). There were more marketable fruit at $1^{\circ} \mathrm{C}$ regardless of fruit maturity stages; however at $5^{\circ} \mathrm{C}$, fruit harvested at the maturity stage E2 showed the lowest healthy fruit percentage, which should be associated with the higher metabolism in E2 and temperature of $5^{\circ} \mathrm{C}$ (Table 1). The higher metabolism showed by fruit stored under $5^{\circ} \mathrm{C}$ is a result of higher respiration rate, cell wall enzymes activity, decreasing the cell resistance what may result in damage to the fruit leading in lower healthy fruits amount. The higher cell wall degradation transformed pectin, celluloses and hemicelluloses in soluble sugar, which increase the soluble solids content (Table 1). According some researches carried out early the cell wall enzyme activity, such as polygalacturonase and pectinmethylesterase (PRASANNA et al., 2007; PAYASI et al., 2009), reduced the fruit firmness and resistance to damage, what could explain the lower healthy fruit reported in the highest storage temperature. 


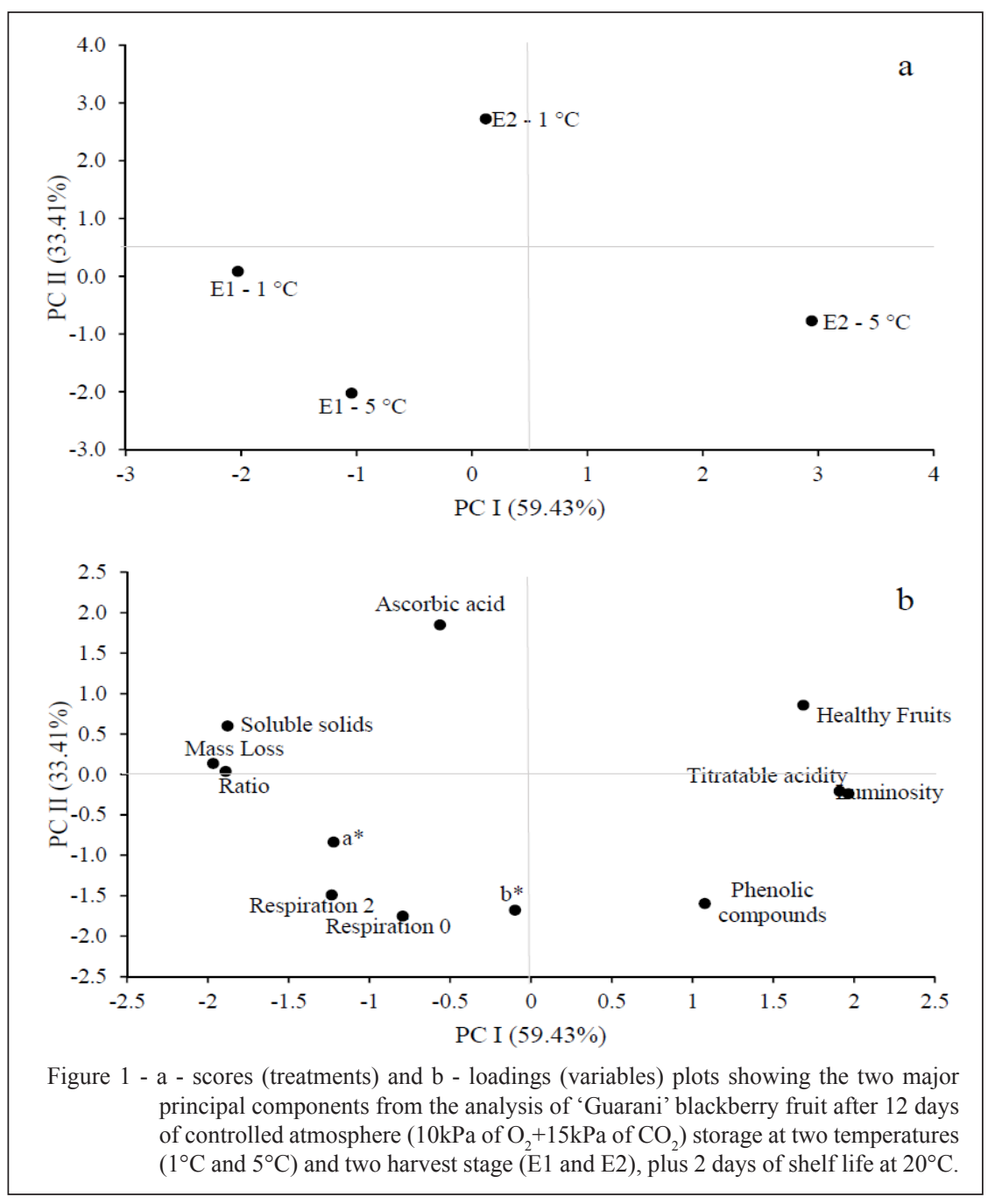

Acids are important subtracts for fruit respiration, so than higher acid concentration lower fruit metabolism during storage. Titratable acidity were lower in fruits stored at $5^{\circ} \mathrm{C}$, which can be related to the higher fruit metabolism in this temperature, showed by higher respiration rate (STEFFENS et al., 2007). In 'Brazos' and 'Comanche' blackberries the titratable acidity were reduced as storage period increase (ANTUNES et al., 2003). Low temperature reduced organic acids degradation during storage, due to the lower respiration rate at $1{ }^{\circ} \mathrm{C}$. Fruit at maturity stage E1 showed a decrease of acidity, whereas in E2 there was an increase, probably due to the high mass loss in E2, which can concentrate solutes, considering that the solute concentration occur alongside mass loss, such as in apples (BRACKMANN et al., 2007), peaches (PINTO et al., 2012) and persimmons (BRACKMANN et al., 2014).
The SS/TA ratio, was higher in fruit harvest in E2 (average 8.81), showing higher sugar in relationship with lower acidity levels. Fruit harvested in E1 showed a ratio average of 3.98, which indicated high acidity and low SS contents, which are not appropriate to consumption for Brazilian consumers, especially due to the high TA and low SS. For strawberries, RESENDE et al. (2008) verified that high ratio SS/ TA value are associated to better flavor perception by the consumers, justifying the higher sensory quality of blackberries harvested in E2. Therefore, despite the best conservation (healthy fruit and low mass loss) the E1 maturation stage is not indicated for harvest, since the fruits did not achieve high quality, even when stored under higher temperature, because of its lower ratio and undesired coloration (Table1).

Fruit harvested in both maturity stages presented higher soluble solids content at $5^{\circ} \mathrm{C}$ 
Table 1 - Metabolism and quality of 'Guarani' blackberry fruit after 12 days of controlled atmosphere $\left(10 \mathrm{kPa}\right.$ of $\mathrm{O}_{2}+15 \mathrm{kPa}$ of $\left.\mathrm{CO}_{2}\right)$ storage at two temperatures $\left(1^{\circ} \mathrm{C}\right.$ and $\left.5^{\circ} \mathrm{C}\right)$ and two harvest stage $\left(\mathrm{E} 1\right.$ and E2), plus 2 days of shelf life at $20^{\circ} \mathrm{C}$.

\begin{tabular}{|c|c|c|c|c|c|c|}
\hline Temperature & $\mathrm{E} 1^{*}$ & E2 & Mean & E1 & E2 & Mean \\
\hline & \multicolumn{3}{|c|}{------------------------Mass Loss (\%)----------------------- } & \multicolumn{3}{|c|}{ 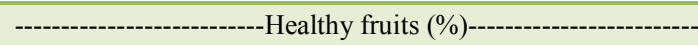 } \\
\hline At harvest & 0.0 & 0.0 & - & 100.0 & 100.0 & - \\
\hline $1.0^{\circ} \mathrm{C}$ & 0.54 & 1.27 & $0.91 \mathrm{a}$ & $82.41 \mathrm{Aa}$ & $80.14 \mathrm{Aa}$ & 81.27 \\
\hline $5.0^{\circ} \mathrm{C}$ & 0.19 & 1.54 & $0.87 \mathrm{a}$ & $71.84 \mathrm{Ab}$ & $57.56 \mathrm{Bb}$ & 64.70 \\
\hline \multirow[t]{2}{*}{ Mean } & $0.36 \mathrm{~B}^{* *}$ & $1.41 \mathrm{~A}$ & - & 77.12 & 68.85 & - \\
\hline & \multicolumn{3}{|c|}{----------------------------SS (Brix)---------------------------- } & \multicolumn{3}{|c|}{-------------------TA (mEq of $\mathrm{NaOH} 100 \mathrm{~mL}$ )---------------- } \\
\hline At harvest & 5.70 & 7.75 & - & 2.09 & 1.16 & - \\
\hline $1.0^{\circ} \mathrm{C}$ & $5.26 \mathrm{Ab}$ & $5.08 \mathrm{Ab}$ & 5.17 & $19.02 \mathrm{Ba}$ & $21.81 \mathrm{Aa}$ & 20.41 \\
\hline $5.0^{\circ} \mathrm{C}$ & 7.12Aa & $6.40 \mathrm{Ba}$ & 6,76 & $12.59 \mathrm{Ab}$ & $11.76 \mathrm{Ab}$ & 12.17 \\
\hline \multirow[t]{2}{*}{ Mean } & 6.19 & 5.74 & - & 15.80 & 16.78 & - \\
\hline & \multicolumn{3}{|c|}{ 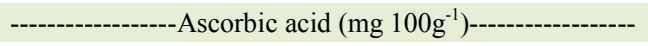 } & \multicolumn{3}{|c|}{ 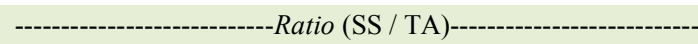 } \\
\hline At harvest & 36.54 & 63.40 & - & 2.73 & 6.76 & - \\
\hline $1.0^{\circ} \mathrm{C}$ & $24.66 \mathrm{Ab}$ & $15.41 \mathrm{Ba}$ & 20.04 & 4.32 & 8.76 & $6.54 \mathrm{a}$ \\
\hline $5.0^{\circ} \mathrm{C}$ & $31.48 \mathrm{Aa}$ & $16.29 \mathrm{Ba}$ & 24.08 & 3.65 & 8.87 & $6.26 \mathrm{a}$ \\
\hline \multirow[t]{2}{*}{ Mean } & 28.07 & 15.85 & - & $3.98 \mathrm{~B}$ & $8.81 \mathrm{~A}$ & - \\
\hline & \multicolumn{3}{|c|}{--Respiration rate Open of chambers $\left(\mathrm{mL} \mathrm{CO}_{2} \mathrm{~kg}^{-1} \mathrm{~h}^{-1}\right)--$} & \multicolumn{3}{|c|}{--Respiration rate Two days of shelf life $\left(\mathrm{mL} \mathrm{CO}_{2} \mathrm{~kg}^{-1} \mathrm{~h}^{-1}\right)--$} \\
\hline At harvest & - & - & - & - & - & - \\
\hline $1.0^{\circ} \mathrm{C}$ & 24.01 & 36.70 & $30.35 b$ & 32.76 & 54.63 & $43.69 b$ \\
\hline $5.0^{\circ} \mathrm{C}$ & 56.38 & 72.72 & $64.55 \mathrm{a}$ & 61.51 & 88.61 & $75.06 \mathrm{a}$ \\
\hline \multirow[t]{2}{*}{ Mean } & $40.19 \mathrm{~B}^{* *}$ & $54.71 \mathrm{~A}$ & - & $47.13 \mathrm{~B}$ & $71.62 \mathrm{~A}$ & - \\
\hline & \multicolumn{3}{|c|}{----------------Phenolic compounds (mg L'1)-------------- } & \multicolumn{3}{|c|}{-----------------------------Luminosity (L)--------------------------- } \\
\hline At harvest & 9.69 & 10.21 & - & 60.85 & 18.88 & - \\
\hline $1.0^{\circ} \mathrm{C}$ & 9.85 & 9.54 & $9.69 b$ & 60.13 & 37.59 & $48.98 \mathrm{a}$ \\
\hline $5.0^{\circ} \mathrm{C}$ & 10.04 & 9.94 & $9.99 a$ & 69.39 & 40.03 & $54.71 \mathrm{a}$ \\
\hline \multirow[t]{2}{*}{ Mean } & $9.95 \mathrm{~A}$ & $9.74 \mathrm{~A}$ & - & $64.73 \mathrm{~A}$ & $38.81 \mathrm{~B}$ & - \\
\hline & \multicolumn{3}{|c|}{-------------------------------- $a^{*}$ values------------------------------ } & \multicolumn{3}{|c|}{-----------------------------------b values--------------------------------- } \\
\hline At harvest & 25.86 & 10.30 & - & 26.19 & 3.19 & - \\
\hline $1.0^{\circ} \mathrm{C}$ & 37.53 & 41.39 & $39.46 a$ & $26.34 \mathrm{Aa}$ & $24.33 \mathrm{Ab}$ & 25.33 \\
\hline $5.0^{\circ} \mathrm{C}$ & 41.16 & 41.18 & $41.17 \mathrm{a}$ & $27.09 \mathrm{Aa}$ & $29.44 \mathrm{Aa}$ & 28.26 \\
\hline \multirow[t]{2}{*}{ Mean } & $39.34 \mathrm{~A}$ & $41.28 \mathrm{~A}$ & - & 26.72 & 26.88 & - \\
\hline & \multicolumn{3}{|c|}{------------------------------Chroma----------------------------- } & \multicolumn{3}{|c|}{ 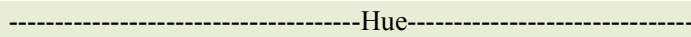 } \\
\hline At harvest & 28.89 & 10.79 & - & 206.5 & 197.0 & - \\
\hline $1.0^{\circ} \mathrm{C}$ & 45.86 & 48.03 & $46.94 \mathrm{a}$ & $215.1 \mathrm{Aa}$ & $210.4 \mathrm{Bb}$ & 212.8 \\
\hline $5.0^{\circ} \mathrm{C}$ & 49.30 & 50.72 & $50.01 \mathrm{a}$ & 213.4Aa & $215.7 \mathrm{Aa}$ & 214.6 \\
\hline Mean & $47.58 \mathrm{~A}$ & 49.37A & - & 214.3 & 213.1 & - \\
\hline
\end{tabular}

${ }^{*}$ Maturity stage, E1 skin of fruit red, E2 skin color black. ${ }^{* *}$ Means followed by equal letters, uppercase in the lines and lowercase in the columns, do not differ by Tukey test, $(\mathrm{P}<0.05)$.

(Table 1). At temperature of $1^{\circ} \mathrm{C}$, soluble solids content did not differ between maturity stages; however, at temperature of $5^{\circ} \mathrm{C}$ fruit harvest in $\mathrm{E} 1$ maturity stage showed higher soluble solids. Probably fruit harvested early had lower respiration rate, decreasing its sugar consumption, resulting in higher soluble solids content. A reduction in the levels of organic acids and soluble solids with the respiration rate increasing has been cited in literature for majority fruits (SWEETMAN et al., 2009; MILLAR et al., 2011), which can explain the findings of this study.
Titratable acidity was higher in fruits stored at $1{ }^{\circ} \mathrm{C}$ and harvested on mature stages E2 (Table 1).

The ascorbic acid content (Table 1) was higher in E1 and at $5^{\circ} \mathrm{C}$. ANTUNES et al. (2003) also identified higher ascorbic acid content, in fruit stored at $20^{\circ} \mathrm{C}$ when compared to $2^{\circ} \mathrm{C}$, up to nine days of storage. Thereafter fruits stored under $2^{\circ} \mathrm{C}$ showed higher ascorbic acid content. However, on our study after 12 days of storage plus 2 days of shelf life fruit stored at $5^{\circ} \mathrm{C}$ showed high ascorbic acid content. Perhaps, the differences of our results and the ones of ANTUNES et 
al. (2003) is due to the storage technology employed, CA on the present study and only cold storage for their study. There was no difference between temperatures in E2. According to AZZOLINI et al. (2004) the decrease in the ascorbic acid content showed in E2 may be due ascorbic acid oxidase enzymes, which show higher activity in black-colored fruits than redcolored, explaining loss at the end of the storage period and fruit senescence. KAFKAS et al. (2006) evaluating five Mediterranean blackberries cultivars (Navaho, Chester Thornless, Loch Ness, Bursa 2 and Jumbo), verified a significant variation in ascorbic acid content for these cultivars, with higher content in cultivar Loch Ness. These authors did not detect ascorbic acid in the cultivars Navaho and Jumbo. In our research, we also reported that ascorbic acid content varies according fruit maturity stage and storage temperature, with a significant interaction between these factors (Table 1).

In relation to respiration rate, there was no interaction between treatments, showing the response for respiration of the two maturity stages was similar in the two temperatures (Table 1). Independently of the maturity stage, higher respiration rate was quantified in fruits at $5^{\circ} \mathrm{C}$. These results of respiration rate are in agreement with the literature, which reported the occurrence of a significant decrease in respiration rate with temperature reduction (STEFFENS et al., 2007; WRIGHT et al., 2010). Comparing the maturity stages, it was observed higher respiration rate in fruit harvested in E2 (Black color of the skin). Probably, the higher respiration rate showed by this fruit is due to the advanced ripening stage of these fruit, once they have lower healthy fruit amount and titratable acidity that are quality indicators parameters.

The phenolic compounds (Table 1) were higher in fruit stored under $5^{\circ} \mathrm{C}$, without significant difference between the maturity stages. TOSUN et al. (2008) and ACOSTA-MONTOYA et al. (2010) reported a significant reduction in total phenolic compounds according the fruit-ripening advance. On average the temperature of $5^{\circ} \mathrm{C}$ demonstrated higher concentration of phenolic compounds. Blackberries have higher phenolic compounds than strawberries and raspberries, whereas classified in flavonoids and not flavonoids (JACQUES \&ZAMBIAZI, 2011).

The fruit juice coloration is an important variable of ripening, especially for blackberry. In relation to the $\mathrm{L}$ values, no significant interaction between factors was observed (Table 1). Evaluating the main effect temperature, no statistical difference happens; however, fruits harvested at early maturity stage E1 showed high L values. TOSUN et al. (2008) reported a significant reduction of luminosity by ripening advance in wild blackberries from Turkey. In relation to $a^{*}$ values and chroma no significant difference was observed (Table 1). However, in relation to coordinate $b^{*}$, a significant interaction among factor happens. Comparing the two maturity stages no statistical difference was identified, independently of the storage temperature adopted. Fruits harvested in E2 (black color of the skin) and thereafter stored under $1^{\circ} \mathrm{C}$ showed a higher blue color (lower $b^{*}$ ). The higher blue color of later harvest fruit (E2) stored under $1^{\circ} \mathrm{C}$ is confirmed by the lower Hue angle (Table 1).

\section{CONCLUSION}

Harvest should not be recommended in the early maturity stage, because 'Guarani' blackberries do not develop all physical and chemical parameters for consumption, even $5^{\circ} \mathrm{C}$ storage temperature.

The best storage temperature of 'Guarani' blackberries is $1^{\circ} \mathrm{C}$.

The harvest has to be carried out at the stage E2 (black-color).

\section{ACKNOWLEDGEMENTS}

To Conselho Nacional de Desenvolvimento Científico e Tecnológico (CNPq) and Coordenação de Aperfeiçoamento de Pessoal de Nível Superior (CAPES), for financial support.

\section{REFERENCES}

ACOSTA-MONTOYA, Ó. et al. Phenolic content and antioxidant capacity of tropical highland blackberry (Rubus adenotrichus Schltdl.) during three edible maturity stages. Food Chemistry, v.119, p.1497-1501, 2010. Available from: <http://www.sciencedirect.com/ science/article/pii/S0308814609010917> . Accessed: Oct. 24, 2016.

AGAR, I.T.et al. Effect of high $\mathrm{CO}_{2}$ and controlled atmosphere (CA) on the ascorbic and dehydroascorbic acid content of some berry fruits. Postharvest Biology and Technology, v.11, 47-55, 1997. Available from: <http://www.sciencedirect.com/science/article/pii/ S0925521497014142>. Accessed: Oct. 20, 2016.

ANTUNES, L.E.C.et al. Conservação pós-colheita de frutos de amoreira-preta. Pesquisa Agropecuária Brasileira, v.38, p.413419, 2003. Available from: <https://www.agencia.cnptia.embrapa. br/Repositorio/3_scielo_pos_colheita_000gi0c039t02wx5ok05va dr1v19s6ts.pdf>. Accessed: Oct. 19, 2016.

ANTUNES, L.E.C. et al. Produção de amoreira-preta no Brasil. Revista Brasileira de Fruticultura, v.36, p.100-111, 2014. Available from: <http://www.scielo.br/scielo.php?script=sci_artt ext\&pid=S0100-29452014000100012>. Accessed: Oct. 19, 2016.

AZZOLINI, M. et al. Índices para avaliar qualidade pós-colheita de goiabas em diferentes estádios de maturação. Pesquisa Agropecuária Brasileira, v.39, p.139-145, 2004. Available from: $<$ http://www.scielo.br/scielo.php?script=sci_arttext\&pid $=$ S0100204X2004000200006>. Accessed: Oct. 25, 2016. 
BOTH, V. et al. Effect of storage under extremely low oxygen on the volatile composition of 'Royal Gala' apples. Food Chemistry, v.156, p.50-57, 2014. Available from: <http://www.sciencedirect.com/ science/article/pii/S0308814614001265>. Accessed: Oct. 15, 2016.

BRACKMANN, A. et al. Indução da perda de massa fresca e a ocorrência de distúrbios fisiológicos em maçãs 'Royal Gala' durante o armazenamento em atmosfera controlada. Revista Brasileira de Armazenamento, v.32, p.87-92, 2007.

BRACKMANN, A. et al. Atmosfera controlada para o armazenamento de goiaba cultivar Paluma. Revista Ceres, v.59, p.151-156, 2012. Available from: $\quad<\mathrm{http} / /$ www.scielo.br/scielo.php?script=sci_artext\&pid=S0034 737X2012000200001>. Accessed: Oct, 20, 2016.

BRACKMANN, A. et al. Respiration rate and its effect on mass loss and chemical qualities of 'Fuyu' persimmon fruits stored in controlled atmosphere. Ciência Rural, v.44, p.612-615, 2014. Available from: $<$ http://www.scielo.br/scielo.php?script=sci_arttext \&pid=S0103-84782014000400006 $>$. Accessed: Oct. 25, 2016.

CIA, P. et al. Atmosfera modificada e refrigeração para conservação pós-colheita da amora-preta. Bioscience Journal, v.23, p.11-16, 2007. Available from: $<$ http://www.seer.ufu.br/index.php/biosciencejournal/ article/view/6668>. Accessed: Oct. 24, 2016.

GONÇALVES, E.D. et al. Manutenção da qualidade pós-colheita de pequenas frutas. Informe Agropecuário, v.33, p.89-95, 2012. Available from: <https://www.embrapa.br/busca-de-publicacoes/-/ publicacao/937094/manutencao-da-qualidade-pos-colheita-daspequenas-frutas $>$. Accessed: Oct. 22, 2016.

JACQUES, A.C.; ZAMBIAZI, R.C. Fitoquímicos em amorapreta (Rubus spp.). Semina: Ciências Agrárias, v.32, p.245-260, 2011. Available from: <http://www.uel.br/revistas/uel/index.php/ semagrarias/article/view/4064>. Accessed: Oct. 25, 2016.

KADER, A.A. Biochemical and physiological basis for effects of controlled and modified atmospheres on fruits and vegetables. Food Technology, v.40, p.99-104, 1986. Available from: <http://ucce. ucdavis.edu/files/datastore/234-399.pdf>. Accessed: Oct. 18, 2016.

KADER, A.A. Postharvest technology of horticultural crops. 3.ed. California: University of California, 2002. 509p.

KAFKAS, E. et al. Analysis of sugars, organic acids and vitamin C content of blackberry genotypes from Turkey. Food Chemistry, v.97, p.732-736, 2006. Available from: <http://www.sciencedirect.com/ science/article/pii/S030881460500796X>. Accessed: Oct. 15, 2016

MILLAR, A.H. et al. Organization and regulation of mitochondrial respiration in plants. Annual Review of Plant Biology, v.62, p.79-104, 2011. Available from: <https://www.ncbi.nlm.nih.gov/ pubmed/21332361>. Accessed: Oct. 24, 2016.

PAYASI, A. et al. Biochemistry of fruit softening: an overview. Physiology and Molecular Biology of Plants, v.15, p.103-113,
2009. Available from: <http://link.springer.com/article/10.1007/ s12298-009-0012-z>. Accessed: Oct, 2016.

PERKINS VEAZIE, P.; COLLINS, J.K. Quality of erect-type blackberry fruit after short intervals of controlled atmosphere storage. Postharvest Biology and Technology, v.25, p.235-239, 2002. Available from: <https:/naldc.nal.usda.gov/download/19504/ PDF>. Accessed: Oct. 26, 2016.

PINTO, J.A.V. et al. Indução de perda de massa na qualidade póscolheita de pêssegos 'Eragil' em armazenamento refrigerado. Ciência Rural, v.42, p.962-968, 2012. Available from: <http://www.scielo.br/ scielo.php?script $=$ sci arttext\&pid $=\mathrm{S} 0103-84782012000600002>$. Accessed: Oct. 14, 2016.

PRASANNA, V. et al. Fruit ripening phenomena an overview. Critical Reviews in Food Science and Nutrition, v.47, p.1-19, 2007. Available from: <https://www.ncbi.nlm.nih.gov/pubmed/17364693>. Accessed: Oct. 19, 2016.

RESENDE, J.T.V. et al. Sensory analysis and chemical characterization of strawberry fruits. Horticultura Brasileira, v.26, p.371-374, 2008. Available from: $<$ http://www.scielo.br/scielo.php?script=sci_arttext\& pid $=$ S0102-05362008000300015 $>$. Accessed: Oct. 15, 2016.

SCHWARZ, A. Relative humidity in cool stores: measurement, control and influence of discreet factors. Acta Horticulturae, v.2, n.368, p.687692, 1994. Available from: <http://www.phtnet.org/research/viewabstract.asp?research_id=wk118>. Accessed: Oct. 20, 2016.

SINGLETON, V.L.; ROSSI JUNIOR, J.A. Colorimetry of total phenolics with phosphomolybdic-phosphotungstic acid reagents. American Journal of Enology and Viticulture, v.16, p.144-158, 1965. Available from: <http://www.ajevonline.org/content/16/3/144> Accessed: Oct. 25, 2016.

STEFFENS, C.A. et al. Taxa respiratória de frutas de clima temperado.Pesquisa Agropecuária Brasileira, v.42, p.313-321, 2007. Available from: $<$ http://www.scielo.br/scielo.php?script=sci arttext\&pid=S0100-204X2007000300003 $>$. Accessed: Oct. 26, 2016.

SWEETMAN, C. et al. Regulation of malate metabolism in grape berry and other developing fruits. Phytochemistry, v.70, p.13291344, 2009. Available from: <http://www.sciencedirect.com/ science/article/pii/S0031942209003392>. Accessed: Oct. 15, 2016.

TOSUN, I.et al. Physical and chemical changes during ripening of blackberry fruits. Scientia Agricola, v.65, p.87-90, 2008. Available from: <http://www.scielo.br/scielo.php?script=sci_artt ext\&pid=S0103-90162008000100012 >. Accessed: Oct. 21, 2016.

WRIGHT, H. et al. The effect of temperature and other factors on chlorophyll $a$ fluorescence and the lower oxygen limit in apples (Malus domestica). Postharvest Biology and Technology, v.55, p.21-28, 2010. Available from: <http://www. sciencedirect.com/science/article/pii/S0925521409001598>. Accessed: Oct. 22, 2016 